DOI https://doi.org/10.18551/rjoas.2018-05.22

\title{
SOCIAL IMPACT OF TOURISM DEVELOPMENT: A STUDY IN GUBUGKLAKAH TOURISM VILLAGE, INDONESIA
}

\author{
Topowijono*, Supriono \\ Tourism Program, Faculty of Administrative Science, University of Brawijaya, Indonesia \\ *E-mail: topo w fia@ub.ac.id
}

\begin{abstract}
Tourism is one of four biggest resource of Indonesian income. The development of Indonesian tourism business is rapid. However, there are both positive and negative impacts behind the rapid development of the business, whether in its social, economic, culture, and safety field. This research is conducted in order to identify the social impact of tourism development in Gubugklakah Tourism Village Malang, Indonesia. The method used in this research was qualitative with descriptive approach. The data were collected through interview using purposive and snowball sampling to determine the respondents. The result of this research shows that there are both positive and negative in social field from the tourism development in Gubugklakah. The positive impact is teenager's delinquency can be directed to a more productive activity. Meanwhile, the negative impact is the environment is disturbed such as voice pollution, trash, and the decrease of original culture of the village rubbed down by the tourists.
\end{abstract}

\section{KEY WORDS}

Tourism, development, policies, business, income.

The increasing of tourism development or tourist visit can cause both positive and negative impact and the objects of the impact are usually the people, environment, economic, and socal field (Lenner in "Tourism: Social, Economic, Environment Impacts", accessed from www.jurnal-sdm.blogspot.com). The development of tourism will have a huge and significant impact toward the economic development, the effort of natural resource and environment conservation, and the social and cultural life of local people. The development of tourism will contribute to the regional income as it will open more business and vocation opportunities, and also function to guard and conserve natural and biological diversity. Tourism development is also one of the general development sectors so it is relevant if the development of the tourism is adjusted the regional potential. The development of tourism is expected to positively influence for the living of local people and encourage other sectors development such as economic, social, and culture field.

The tourism in Gubugklakah, Malang, East Java of Indonesia is a business that is well and professionally managed. According to Purmada (2016) Gubugklakah tourism village has implied community based tourism (CBT) perspective in its management which involves the active role of local people. Department of Tourism Village (Lembaga Desa Wisata/Ladesta) of Gubugklakah is one of the management aspects that sets local people or CBT forward, and to keep its existence in business there should be a good management and strategy to run this business. The local people of Gubugklakah Tourism Village (Desa Wisata Gubugklakah/DWG) who used to work only in agriculture sector, today they start to work in tourism sector. Tourism activity in Gubugklakah Tourism Village is held and managed by a community called Pokdarwis (kelompok sadar wisata) or Ladesta of Gubugklakah. By the development of tourism it has several impacts especially in social field. Therefore, the purpose of this research is to describe the social impact happens to the local people of Gubugklakah as the result of tourism development in that area.

\section{LITERATURE REVIEW}

Tourism development is a series of efforts to build cohesiveness in the usage of many tourism resources, integrating many aspects outside the tourism which directly or indirectly related toward the existence of tourism development (Swarbrooke 1996). 
According to Pendit (2009:128) local people and their culture tend to change as a result of the existence of tourism site in the area. The impact of tourism toward social cultural living is mainly to answer three main questions, they are: what is the characteristics of interaction between the tourist and local people (host-guest), how tourism change local people and culture, and does the change give advantage or harm toward the host.

Cohen (in Hirawan 2008) explained social impact of tourism which is classified into ten main categories as follows:

1. The impact toward relationship and involvement of local people and the wider people, including the level of autonomy and dependency;

2. The impact toward interpersonal relationship among individuals;

3. The impact toward social organization/department foundation;

4. The impact toward migration into and from the tourism area;

5. The impact toward the rhythm of local people social life;

6. The impact toward work distribution pattern;

7. The impact toward social stratification and mobility;

8. The impact toward power and influence distribution;

9. The impact toward the increasing of social deviations;

10. The impact toward art and culture field.

Meanwhile, according to Richardson and Fluker (2004) the impacts of tourism toward the socio-cultural life in the tourism area are as follows:

The impact toward population structure. The increasing of tourism activity in an area needs personnel to run the business and to provide the service needed by the tourism. Some of them maybe come from local who decides to change their profession from another sector to tourism sector. Others may decide to stay live in its surrounding area although they are not recruited to work in the tourism sector rather than moving to other place because of the limited opportunity. Another possibility is the coming of people from another region to work in the area because of the tourism.

Transformation of livelihood structure. It has to be admitted that the opportunity to work in tourism sector has several benefits compared to other sector. It will suddenly attract people's interest from other job and region to move closer to tourism sector. Some regions where most of the people generally work in agricultural sector are soon to face challenge. There will be job and employee transformation from agricultural sector to tourism sector. Some types of profession which do not need special skill in tourism sector such as gardener, cleaning service, house-keeping, and the like will attract housewives or agricultural worker to join. The characteristic of tourism which is seasonal sometimes socially affect local people who are happened to work in tourism sector.

Tranformation of value. The increasing of population because of the new comer with different attitude will cause value interference in the tourism area. The impact of tourism toward the value in the area is more because the influence of the tourist rather that the influence of tourism worker who comes from other region. The transformation of value can be as follows:

- Demonstration effect;

- Marginalization;

- Culture commodification.

The impact toward daily life. Beside its impact toward values and the way people think, tourism also cause problem for local people which affect the way they act in their daily life.

Based on previous explanation there are two kinds of impact appear from the development of tourism, they are positive and negative impact. The impact can be direct or indirect. In general, the development of tourism affects the economic, social, religion, and culture.

\section{METHODS OF RESEARCH}

This research used descriptive qualitative method. The data were collecting using indepth interview technique. The respondents were determined using snowball sampling with 
the head of the village as key informant which was purposively chosen. The data were processed using data triangulation technique.

\section{RESULTS AND DISCUSSION}

The impact of tourism toward social cultural living is mainly to answer three main questions, they are: what is the characteristics of interaction between the tourist and local people (host-guest), how tourism change local people and culture, and does the change give advantage or harm toward the host. Tourism development in Gubugklakah Tourism Village influences its social field. It also contributes both positive and negative values. The positive values occur because of tourism activity is that teenagers delinquency can be directed into more positive activity that is tourism itself. However, there are also negative effects of the tourism such as the traffic becomes more crowded which causes sound and air pollution, while in the social aspect tourism development affect the rusticity character and local culture started to fade also the mindset of local people turns to be material oriented.

According to Pendit (2009:128) local people and their culture tend to change as a result of the existence of tourism site in the area. The impact of tourism toward social cultural living is mainly to answer three main questions, they are: what is the characteristics of interaction between the tourist and local people (host-guest), how tourism change local people and culture, and does the change give advantage or harm toward the host. Cohen (1995) explained social impact of tourism which is classified into ten main categories as follows: the impact toward relationship and involvement of local people and the wider people, including the level of autonomy and dependency; the impact toward interpersonal relationship among individuals; the impact toward social organization/department foundation; the impact toward migration into and from the tourism area; the impact toward the rhythm of local people social life; the impact toward work distribution pattern; the impact toward social stratification and mobility; the impact toward power and influence distribution; the impact toward the increasing of social deviations; the impact toward art and culture field.

Tourism development in Gubugklakah Tourism Village influences its social field. It also contributes both positive and negative values.

Positive Impact. The positive value of tourism activity is that teenager's delinquency can be minimalized and directed into more positive activity that is the tourism itself. Those teenagers who are previously unemployment after they are graduated, they have a new activity which is serving the guests. Those teenagers are even accommodated in a community named Lembaga Desa Wisata (LADESTA) of Gubugklakah. This community is responsible for coordinating the teenagers in serving the guests. There is always new guest comes everyday so they do not have time to be directed into negative activity (such as drugs, alcoholic drink, etc.).

Besides, the village institutional becomes stronger. The village's officer does not expect any negative effect from the tourist who comes frequently. This institutional is functioned to solve the problem which is feared to happen. Those institutional are Security, Village's Welfare Department (badan kesejahteraan desa), Tourism Village Department (lembaga desa wisata), etc.

Work distribution also changes to be more positive. There is certain section for providing medium and infrastructure to support the activity so there will not be income accumulation for those who has bigger financial support. Who those with good financial support, they are allowed to build homestay and vehicle rent (car/hardtop). Meanwhile, for those who are not supported financially, they can work as tour guide, driver, or tourism destination organizer (such as organizing animal farm for tourism destination).

Negative Impact. It is not only positive impact happens as the result of tourism development in Gubugklakah, but also negative effect toward its social live; for example, the traffic becomes more crowded which causes sound and air pollution. Gubugklakah used to be a quiet and peaceful village without any vehicle passing by the village. Since it is proclaimed as a tourism village, and there are more visitors come in the condition of this 
village becomes more crowded and noisy especially in holiday. Big and small vehicles are coming in which do not balance the condition of the small road of the village.

And then for the social side that is the rusticity and local culture started to fade and people's mindset tends to be material oriented. The fading rusticity and local culture becomes certain harm for tourism development because the tourist are coming with their culture, it of course affects the local culture and triggers foreign cultures' imitation or adaptation. This condition also triggers awareness in the tourism development toward the negative social impact such as free sex and drugs distribution. These negative impacts also become obstacle for the tourism development. The obstacle can be people's mindset which is already influenced by the tourist culture that causes the change of local culture. This condition will make the local wisdoms disappear as the result of cultural intercourse between local people and the tourist. The awareness of social negative impact such as free sex and drugs distribution also becomes an obstacle in the tourism development because Gubugklakah Tourism Village still does not have any plan to minimalize or wipe off the negative effect. Therefore the implication of tourism development is still conducted in a simple way without mature planning.

Tourism activity can trigger negative impact toward the social and environmental sector if it is not managed well such as a mound of trash which is the result of tourism activity. It also becomes an example of carelessly trashing that cause dirty view. It is possibly from each individual whether it is the tourist or the local people. Therefore, it needs sanitation education for both tourist and local people in the process of tourism development.

\section{CONCLUSION AND SUGGESTIONS}

The fading rusticity and local culture becomes certain harm for tourism development because the tourist are coming with their culture, it of course affects the local culture and triggers foreign cultures' imitation or adaptation. This condition also triggers awareness in the tourism development toward the negative social impact such as free sex and drugs distribution. These negative impacts also become obstacle for the tourism development. The obstacle can be people's mindset which is already influenced by the tourist culture that causes the change of local culture. This condition will make the local wisdoms disappear as the result of cultural intercourse between local people and the tourist. The awareness of social negative impact such as free sex and drugs distribution also becomes an obstacle in the tourism development because Gubugklakah Tourism Village still does not have any plan to minimalize or wipe off the negative effect. Therefore the implication of tourism development is still conducted in a simple way without mature planning.

Optimizing the involvement local people in Gubugklakah Tourism Village is expected to make them are able to become fully independent tourism people and are able to move and develop the tourism through their own idea, tradition, and potential as a local wisdom so they are not depended on the government anymore. The people are expected to be able to select foreign culture which is possible to acculturate with local culture without wiping out the local wisdom. The next researcher can conduct a study of the impact of tourism development in Gubugklakah Tourism Village. Besides, there can be a study about a strategy making of tourism development in Gubugklakah Tourism Village or a study about tourism business competitiveness of in Gubugklakah Tourism Village in the effort to increase local people's well-being.

\section{REFERENCES}

1. Cohen, L. (1995), Quality Function Deployment: How to Make QFD Work for You, Inc.

2. Pendit, 2009. Ilmu Pariwisata Sebuah Pengantar Perdana. Jakarta: Pradnya Paramita.

3. Purmada, 2016. Pengelolaan Desa Wisata Dalam Perspektif Community. Based Tourism Studi Kasus pada Desa Wisata Gubugklakah, Kecamatan. Research Report. Brawijaya.

4. Richardson, 2004. Understanding and Managing Tourism. Australia: Sidney.

5. Swarbrooke. 1996. Pengembangan Pariwisata. Jakarta: Gramedia. Pustaka Utama. 